\title{
CYTOMORPHOLOGY OF FIBROADENOMA AND PHYLLODES TUMOUR: DIAGNOSTIC PERSPECTIVE - ONE YEAR STUDY AT TERTIARY CARE CENTRE
}

\author{
Manimekhala1, Archana Bommana², Ezhil Arasi Nagamuthu³, L. Aruna 4 , Mohammad Abdul Aleem5, Madhukar Reddy Kadaru 6 \\ ${ }^{1}$ Associate Professor, Department of Pathology, Osmania Medical College, Hyderabad, Telangana. \\ ${ }^{2}$ Senior Resident, Department of Pathology, Osmania Medical College, Hyderabad, Telangana. \\ 3 Professor and HOD, Department of Pathology, Osmania Medical College, Hyderabad, Telangana. \\ ${ }^{4}$ Assistant Professor, Department of Pathology, Osmania Medical College, Hyderabad, Telangana. \\ ${ }^{5}$ Final Year Postgraduate, Department of Pathology, Osmania Medical College, Hyderabad, Telangana. \\ ${ }^{6}$ Senior Resident, Department of Pathology, Osmania Medical College, Hyderabad, Telangana.
}

\section{ABSTRACT}

\section{BACKGROUND}

Distinction between Fibroadenoma and Phyllodes tumour is important. Accurate diagnosis of these lesions can be arrived at based upon the triple assessment approach comprising of clinical history and examination; radiological and pathologic examina tions. Fine Needle Aspiration Cytology (FNAC) is widely and commonly adopted minimally invasive technique for the pathologic assessment because of its relative accuracy, sensitivity, specificity and ease of use. Distinction between a cellular fibroadenoma and phyllodes tumour poses diagnostic challenge from cytopathologist's perception due to many overlapping features between the two entities. Thorough analysis of cytology smears helps in categorisation of these tumours helping in arriving at a definitive diagnosis.

\section{METHODS}

The study included 165 patients who presented to our outpatient department, Osmania General Hospital, as breast lump during one year study period between March 2015 and March 2016. FNAC was done for all the cases and their cytomorphological features were studied.

A retrospective study of Fine Needle Aspiration Cytology (FNAC) of breast lumps was done and their cytomorphological features were studied and analysed to categorise them into Fibroadenoma and Phyllodes tumour respectively.

\section{RESULTS}

Out of 165 cases presenting with breast lump, the study revealed 55 (33.3\%) cases of Fibroadenomas, 10 (6.06\%) cases of Phyllodes tumour and the remaining cases were categorised into other breast lesions.

\section{CONCLUSION}

In conclusion the present study emphasised the importance of FNAC, which is a minimally invasive OPD technique which helps in distinction of Fibroadenoma and Phyllodes tumour based on their cytomorphological features, thus providing a quick and near accurate diagnosis.

\section{KEYWORDS}

Fibroadenoma, Phyllodes Tumour, Fine Needle Aspiration Cytology (FNAC), Cytomorphological Features.

HOW TO CITE THIS ARTICLE: Manimekhala, Bommana A, Nagamuthu EA, et al. Cytomorphology of fibroadenoma and phyllodes tumour: diagnostic perspective - one year study at tertiary care centre. J. Evolution Med. Dent. Sci. 2016;5(80):5974-5979, DOI: 10.14260/Jemds/2016/1349

\section{BACKGROUND}

Fibroadenoma is a common benign breast lesion, characteristically containing both stromal and epithelial cells.(1) They occur in women of 10 and 40 years' age group (adolescent and young population).(2,3)

Phyllodes tumours are fibroepithelial tumours composed of an epithelial and a cellular stromal component. They make upto $0.3-0.5 \%$ of all female breast tumours and have an

Financial or Other, Competing Interest: None.

Submission 15-07-2016, Peer Review 24-09-2016,

Acceptance 30-09-2016, Published 06-10-2016.

Corresponding Author:

Dr. Archana Bommana

House No: 2-2-647/41,

Central Excise Colony,

Bagh Amberpet,

Hyderabad-500013.

E-mail: archana.prcp@gmail.com

DOI: $10.14260 /$ jemds $/ 2016 / 1349$ incidence of about 2.1 per million population.(4) The peak incidence occurs in the women aged 45 to 49 years. ${ }^{(5,6)}$ It was believed to be benign until 1943, when Cooper and Ackerman reported on the malignant biological potential of this tumour. They are categorised into benign, borderline or malignant depending on the cytological features, stromal cellularity, infiltration at edge of the tumour and mitotic activity.

\footnotetext{
AIM

To identify cytomorphological features that helps to categorise fibroadenoma from phyllodes tumour based on fine needle aspiration cytology smears studied during the period 20152016.

\section{MATERIALS AND METHODS}

This is a retrospective study conducted at our tertiary institute, which included 165 patients presenting with breast lump during one year study period March 2015 to March 2016.
} 


\section{Inclusion Criteria}

1. All the cases presenting as breast lump were included in the study.

2. All the cases had first time presentation to our OPD and were newly diagnosed.

\section{Exclusion Criteria}

1. All the cases, which were already diagnosed with specific breast disease.

2. All the cases who were previously operated/treated.

3. All the cases with recurrence.

All the cases were subjected for ultrasound examination, reports were available for the study. Ultrasound findings for Fibroadenoma and Phyllodes were collected and were correlated with FNAC findings. After general and local examination, FNAC was performed for selected cases for the study. All the smears obtained from the patients were studied and analysed for cytomorphological features of these lesions.

\section{Cytomorphologic Features of Fibroadenoma}

- Grossly, the aspirate appeared sticky and tenacious, often clogging within the needle lumen.

- Smears were hypercellular with a characteristic biphasic appearance (epithelium and mesenchymal/stromal tissue).

- Cohesive epithelial clusters, monolayered sheets of wellorganised ductal-type epithelium with foldings, branchings with a "papillary like" architecture ("staghorn").

- Naked bipolar myoepithelial nuclei were scattered in the background in a significant number of cases.

- Fibromyxoid stroma.

- Uncommon features - epithelial atypia (nuclear enlargement, crowding, pleomorphism and prominent nucleoli), apocrine and foam cells, prominent mucinous change, multinucleated giant cells and lack of stromal component.

\section{Cytomorphologic Features of Phyllodes Tumour}

- Hypercellular smears, biphasic with epithelial predominance in some (in benign tumours) with large stromal fragments ("phyllodes fragments"), anatomising/branching pattern.

- Large, folded, bland-appearing cohesive epithelial fragments.

- Dissociated spindle and stromal/mesenchymal cells (seen more often in the malignant tumours) with plump fusiform nuclei associated with myxoid or mucinous stromal tissue.

- Stromal fragments were monomorphic, occasional significant atypia.

- Malignant phyllodes tumour was hypercellular, depicting more stromal predominance and with this background we tried to evaluate the cytological features of Phyllodes tumour in our study with special reference to features that can help in distinguishing it from Fibroadenoma, more atypia of the dissociated stromal cells.

\section{RESULTS}

Out of 165 cases presented with breast lump, the study revealed 55 (33.3\%) cases of Fibroadenomas, 10 (6.06\%) cases of Phyllodes tumour, 30 (18.18\%) cases of Fibrocystic disease of breast, 25 (15.15\%) cases of Duct cell carcinoma, 20 $(12.12 \%)$ cases of Mastitis, 25 (15.15\%) cases of Benign proliferative breast disease based on cytomorphological features.

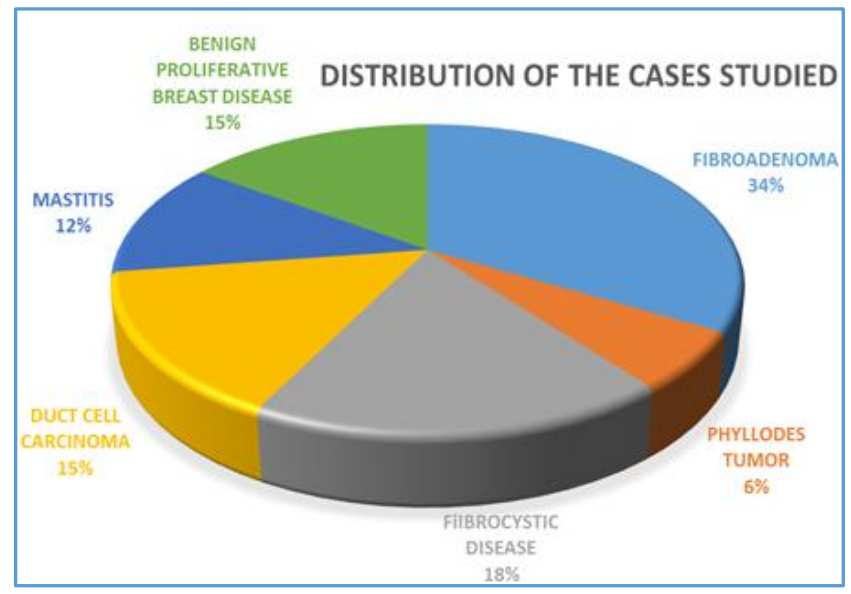

PIE Chart 1

The important criteria that were considered in differentiating Fibroadenoma from Phyllodes tumour in our study were epithelial fragments, larger stromal fragments, numerous plump stromal bare nuclei and the higher ratio of stromal bare nuclei to epithelial bare nuclei in Phyllodes tumours. The cytological smears of all the cases were thoroughly assessed for the cellularity, epithelial to stromal component ratio (qualitative and quantitative), mitotic activity, necrosis. They were categorised into Fibroadenoma and Phyllodes tumour (benign, borderline or malignant) respectively.

In the present study, 55 (85\%) cases showed features consistent with cytomorphological features of fibroadenoma. 7 (11\%) out of 10 cases of Phyllodes tumour showed benignity, while $2(3 \%)$ cases showed cytomorphological features of malignant phyllodes tumour. One (1\%) case showed borderline features.

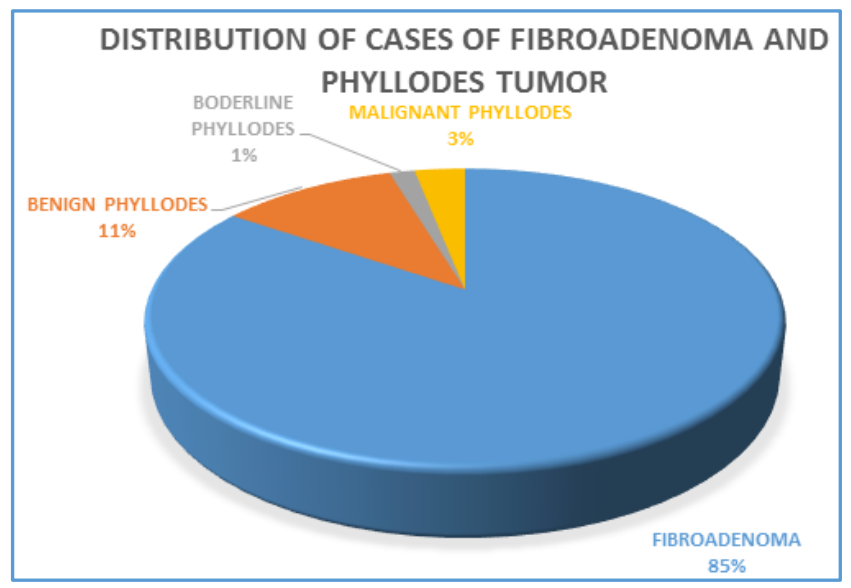

The peak incidence of age group in the study was 25 years and 42 years for Fibroadenoma and Phyllodes tumour respectively. Median size of the lump for Fibroadenoma was 2 $\mathrm{cms}$ and $8 \mathrm{cms}$ for Phyllodes tumour.

All the smears obtained were fixed in 95\% ethanol for 6 hours and were subsequently stained with Haematoxylin and Eosin. 
The cytomorphological features of the cases studied were thoroughly studied, analysed and results were tabulated as shown below [Table 1].

\begin{tabular}{|c|c|c|}
\hline Characteristics & Fibroadenoma & $\begin{array}{c}\text { Phyllodes } \\
\text { Tumour }\end{array}$ \\
\hline $\begin{array}{l}\text { Epithelial } \\
\text { fragments }\end{array}$ & 48 & 03 \\
\hline $\begin{array}{c}\text { Apocrine } \\
\text { metaplasia }\end{array}$ & 30 & 0 \\
\hline Stromal fragments & 36 & 02 \\
\hline Spindle cells & 16 & 09 \\
\hline \multicolumn{3}{|c|}{$\begin{array}{l}\text { Table 1: Comparison of Cytological Characteristics } \\
\text { between Fibroadenoma and Phyllodes in our Study }\end{array}$} \\
\hline
\end{tabular}

Cytomorphological features of Fibroadenoma that were studied showed cohesive, branching monolayered sheets ("staghorn") with honeycombing pattern of well-organised ductal-type epithelium, (Figure - 1) and fibromyxoid stroma (Figure - 2).

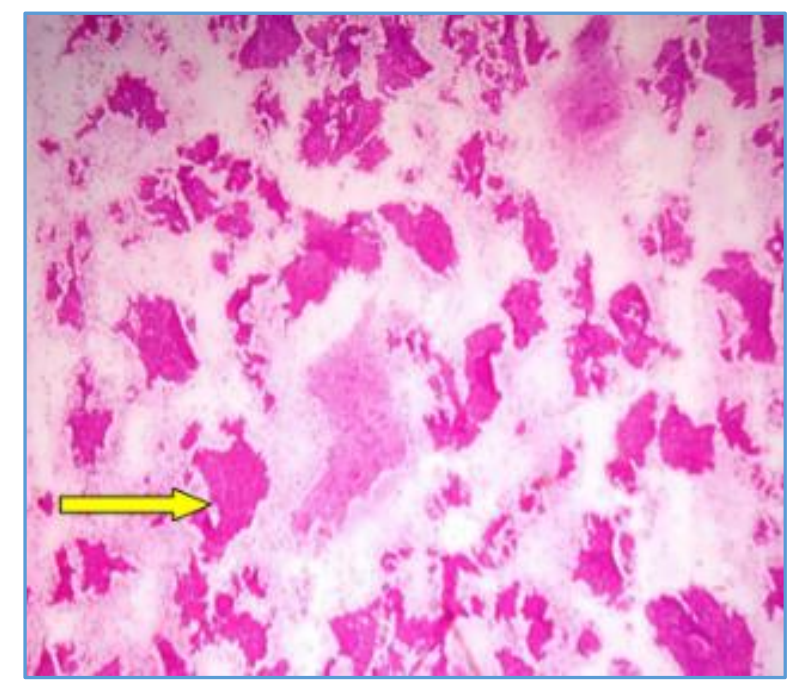

Fig. 1: H \& E Stained Cytosmears show Cytomorphological Features of Fibroadenoma that were Studied showed Cohesive, Monolayered Sheets with Honeycombing Pattern of Well-Organised Ductal-Type Epithelium with Branchings of "Papillary-Like" Architecture ("Staghorn")

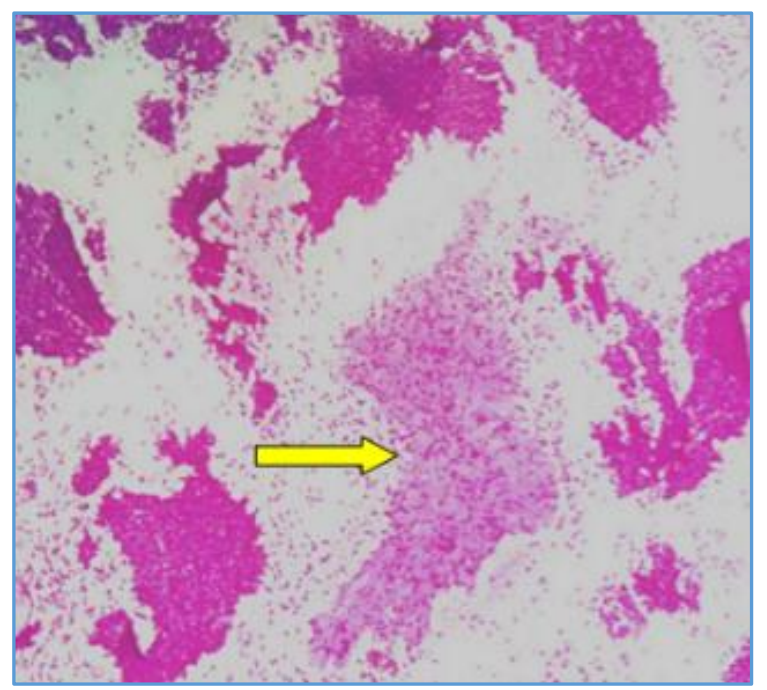

Fig. 2: H \& E Stained Cytosmears show Fibromyxoid Stroma

The cytology findings were correlated with histopathological examination (Figure- 5, 6) and immunohistochemistry confirmation. Vimentin (Figure-7) showed strong cytoplasmic positivity, whereas Pancytokeratin (Figure-8) showed membranous and cytoplasmic positivity for stromal and epithelial components respectively.
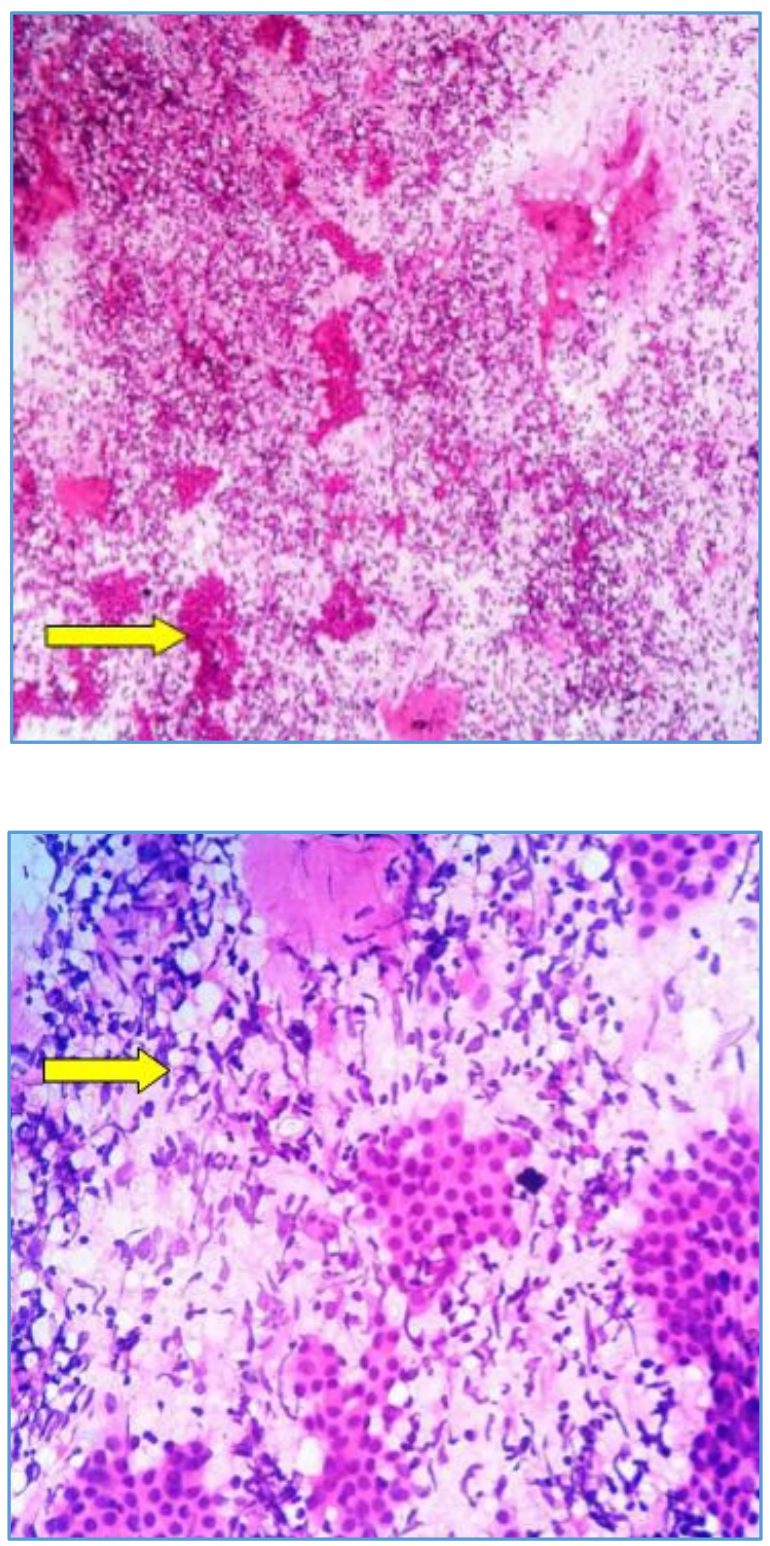

Fig. 3, 4: H \& E Stained Cytosmears show Cytomorphological Features of Phyllodes Tumour showed Hypercellular Smears, Biphasic Pattern with Sparse Epithelial and Large Spindled Stromal Fragments

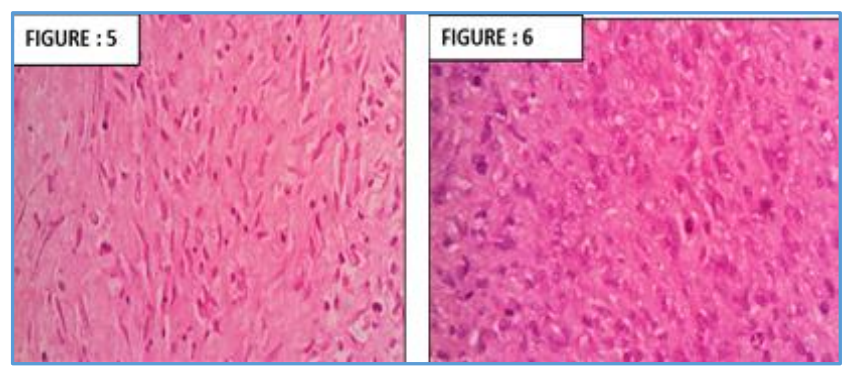

Fig. 5, 6: Histopathological Examination shows H \& E Stained Sections show Stromal Fragments with Plump Spindle Shaped Vesicular Nuclei and Mitotic Activity 


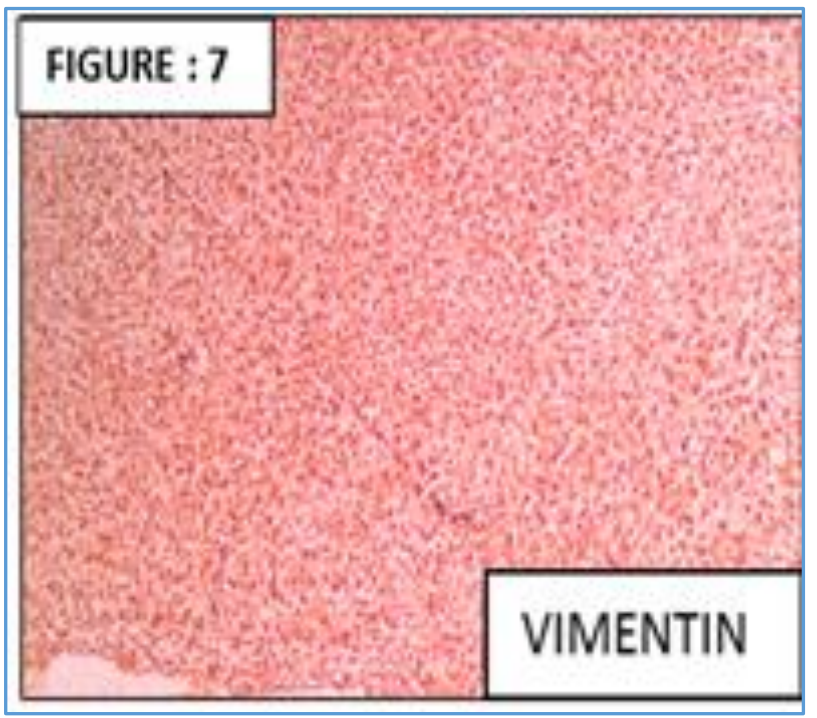

Fig. 7: Immunohistochemistry showing Vimentin showing Strong Cytoplasmic Positivity

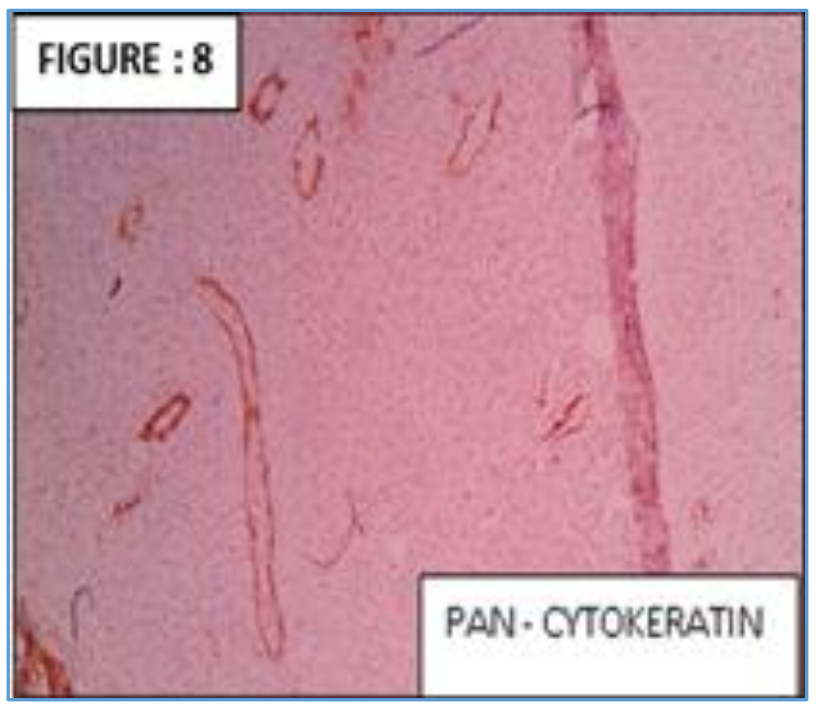

Fig. 8: Immunohistochemistry showing Pan-Cytokeratin Membranous and Cytoplasmic Positivity

\section{DISCUSSION}

Fibroadenoma is the most common benign lesion of female breast which are well-circumscribed, freely movable, rubbery masses resulting from both stromal and glandular proliferation.(7) They are common in young women in 10 to 40 years' age group.

Phyllodes tumours are biphasic fibroepithelial tumours making upto $0.3-0.5 \%$ of all female breast tumours. Phyllodes tumour is the term currently preferred nomenclature. It was named as Cystosarcoma ("fleshy tumour") Phyllodes ("leaflike") by Johannes Müller in 1838. Chelius in 1827 was the first person who described this tumour.(8) They are also known as "Serocystic disease of Brodie."(9)

\section{CLASSIFICATION}

Fibroadenomas can show rapid and massive growth resulting in giant fibroadenoma ( $>5 \mathrm{~cm}$ ) in diameter, constituting $<4 \%$ of them. They are classified into:

1. Adult type.

2. Juvenile type.
Phyllodes Tumour are Classified as

- Non-cancerous (Benign) tumours - These make up about $50-60 \%$ of phyllodes tumours.

- Borderline tumours - These are not yet malignant (cancerous), but are more likely to turn malignant.

- Cancerous (malignant) tumours - These make up about $20-25 \%$ of all phyllodes tumours.

World Health Organisation divided Phyllodes tumour into Benign, Borderline and Malignant categories based on the degree of stromal cellular atypia, mitotic activity per 10 highpower fields, degree of stromal overgrowth (these three are main), tumour necrosis and margin appearance.(10)

\section{Aetiology and Pathogenesis}

Clonal analysis using gene amplification by Polymerase Chain Reaction (PCR) has shown that Fibroadenomas were polyclonal in both epithelium and stroma, whereas the Phyllodes tumour was polyclonal in epithelial cells and was monoclonal in stromal cells.(11) Noguchi et al(12) showed that fibroadenomas have polyclonal elements (HUMARA assay) ${ }^{13}$ with somatic mutations and should be regarded as hyperplastic lesions.(9) Most fibroadenomas are derived from progenitor cells.(14) Comparative Genomic Hybridisation (CGH) analysis showed gain of $1 \mathrm{q}$ and loss of material on 3p.(15) Trauma, lactation, pregnancy, increased oestrogen activity, Endothelin - 1 plays an important role.

\section{DIAGNOSIS}

\section{Clinical Presentation}

Fibroadenoma presents as lump in the breast, freely movable like "breast mouse." Phyllodes tumours manifest as larger masses with rapid growth.(16)

On mammography, fibroadenomas appear as wellcircumscribed discrete oval or round masses; Phyllodes tumours have a radiolucent halo and coarse internal macrocalcifications.(17) On Ultrasound they typically appear as well-circumscribed, round-to-ovoid hypoechoic masses.(18) Phyllodes tumour are inhomogeneous, solid-appearing mass with internal cystic spaces. On Magnetic Resonance Imaging, fibroadenomas appear hypo to isointense on T1W images and iso to hyperintense on T2W image. Phyllodes tumour appears more heterogeneous.(19)

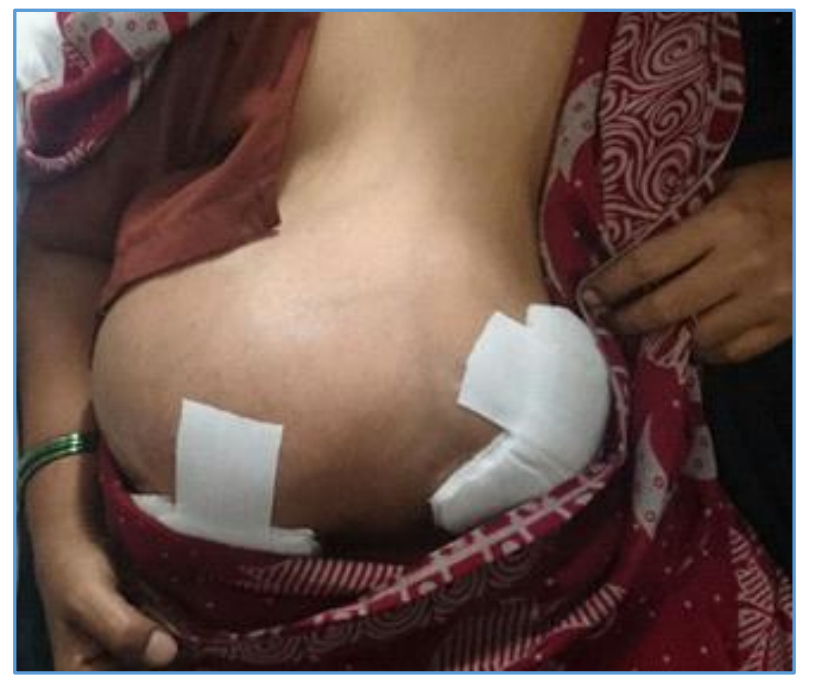

Fig. 9: Clinical Picture of Huge Breast Lump Occupying the Entire Right Breast 
Figure - 9 shows clinical picture of huge breast lump occupying the entire right breast (Phyllodes tumour).

Diagnosis of Phyllodes tumours can be challenging based on Fine Needle Aspiration Cytology (FNAC) smears, because these tumours have similar cytomorphological features to that of a Fibroadenoma.

World Health Organisation Criteria for Phyllodes Tumour

\begin{tabular}{|c|c|c|c|}
\hline Criteria & Benign & Borderline & Malignant \\
\hline $\begin{array}{c}\text { Stromal } \\
\text { cellularity and } \\
\text { atypia }\end{array}$ & Minimal & Moderate & Marked \\
\hline $\begin{array}{c}\text { Stromal } \\
\text { overgrowth }\end{array}$ & Minimal & Moderate & Marked \\
\hline Mitosis/10hpf & $0-4$ & $5-9$ & $>10$ \\
\hline $\begin{array}{c}\text { Tumour } \\
\text { margins }\end{array}$ & $\begin{array}{c}\text { Well- } \\
\text { circumscribed } \\
\text { with pushing }\end{array}$ & $\begin{array}{c}\text { Zone of } \\
\text { microscopic } \\
\text { invasion }\end{array}$ & $\begin{array}{c}\text { Infiltrative } \\
\text { tumour } \\
\text { margins }\end{array}$ \\
\hline
\end{tabular}

\section{Comparison Studies}

The cytomorphological features of our study cases were thoroughly studied, compared with World Health Organisation criteria. The results obtained were as follows:

\begin{tabular}{|c|c|c|c|c|}
\hline Criteria & Fibroadenoma & $\begin{array}{c}\text { Phyllodes } \\
\text { Tumour (Benign) }\end{array}$ & $\begin{array}{c}\text { Phyllodes Tumour } \\
\text { (Borderline) }\end{array}$ & $\begin{array}{c}\text { Phyllodes Tumour } \\
\text { (Malignant) }\end{array}$ \\
\hline Epithelial component & $\begin{array}{c}\text { Minimal (11) } \\
\text { Moderate - } \\
\text { High(44) }\end{array}$ & Minimal(2) & Moderate(1) & High(0) \\
\hline Stromal component & $\begin{array}{c}\text { Fibromyxoid } \\
\text { stroma (36) }\end{array}$ & Minimal(5) & Moderate(0) & High(2) \\
\hline Atypia & $(0)$ & Minimal(4) & Moderate(0) & High(2) \\
\hline Mitotic activity/10hpf & $(0)$ & $<5(5)$ & $(0)$ & $(1)$ \\
\hline Heterologous differentiation & $(0)$ & $(0)$ & $(1)$ & $(2)$ \\
\hline Tumour margins - & $(0)$ & $(0)$ & $(0)$ & $(2)$ \\
\hline Infiltrative/pushing margins & \multicolumn{2}{|c|}{ Table 2: Comparison of Our Study with WHO Criteria } \\
\hline
\end{tabular}

The cytomorphological features of our study cases were compared with Azzopardi and Salvadori et al criteria. The results obtained were as follows:

\begin{tabular}{|c|c|c|c|}
\hline Criteria & Benign & Borderline & Malignant \\
\hline $\begin{array}{c}\text { Tumour margins } \\
\text { (Pushing/Infiltrating) }\end{array}$ & 0 & 01 & 02 \\
\hline Stromal cellularity & Low $(05)$ & Moderate $(0)$ & High(02) \\
\hline Mitotic rate & $<5(5)$ & $5-9(0)$ & $>10(2)$ \\
\hline Pleomorphism & Mild(4) & Moderate $(0)$ & Severe $(2)$ \\
\hline Table 3: Comparison of Our Study with Azzopardi and \\
Salvadori et al for Phyllodes Tumour \\
\hline
\end{tabular}

Scolyer et al(20) proposed that the presence of hypercellular stromal fragments is the most useful finding in distinguishing Phyllodes tumour from Fibroadenomas and the presence of nuclear atypia is useful in separating malignant phyllodes tumour from benign tumours.(21) Our study also showed that stromal fragments, nuclear atypia were important criteria in distinguishing these tumours which was consistent with Scolyer et al study.

Treatment for Fibroadenoma and Phyllodes tumour is complete excision and further follow-up as both of the benign breast diseases have tendency for recurrence. However, the possibility for local recurrence after excision always exists, particularly with lesions that display malignant cytology.(22)

\begin{tabular}{|c|c|c|c|}
\hline & $\begin{array}{c}\text { tumour } \\
\text { margins }\end{array}$ & $\begin{array}{c}\text { around } \\
\text { tumour } \\
\text { margins }\end{array}$ & \\
\hline $\begin{array}{c}\text { Heterologous } \\
\text { differentiation }\end{array}$ & Rare & Rare & $\begin{array}{c}\text { Not } \\
\text { uncommon }\end{array}$ \\
\hline $\begin{array}{c}\text { Overall } \\
\text { average } \\
\text { distribution }\end{array}$ & 60 & 20 & 20 \\
\hline
\end{tabular}

\section{Criteria Proposed by Azzopardi and Salvadori et al[8,16]}

\begin{tabular}{|c|c|c|c|}
\hline Criteria & Benign & Borderline & Malignant \\
\hline Tumour margins & Pushing & & Infiltrative \\
\hline Stromal cellularity & Low & Moderate & High \\
\hline Mitotic rate/10hpf & $<5$ & $5-9$ & $>10$ \\
\hline Pleomorphism & Mild & Moderate & Severe \\
\hline
\end{tabular}

If the tumour recurs locally after excision, further local excision or total mastectomy is typically curative.(23,24)

\section{CONCLUSION}

Though FNAC has advantages and limitations, it has an essential role in the pre-operative management of breast lesions. Its accuracy, ease of use, sensitivity, specificity and affordability are factors that helps its utility in arriving at diagnosis for all accessible and palpable lumps.

Our study based upon adequacy of smears, appreciation of cytomorphological characteristics, relative abundance of stromal fragments, atypia, mitotic activity, tumour margins and epithelial component have helped us in approaching at accurate diagnosis and categorisation of Phyllodes tumour from a cellular Fibroadenoma, thus helping the patients and the clinicians for further follow-up (Recurrence) and better treatment.

\section{REFERENCES}

1. Fiks A. Cystosarcoma phyllodes of the mammary glandmullers tumor. For the 180th birthday of Johannes Müller. Virchows Arch A Pathol Anat Histol 1981;392(1):1-6.

2. Chelius M. Neue jahrbucher der teutschen medicin and chirurgie, naegele und puchelt. Heidelberg, Germany 1827. 
3. Juan R, Vedder AL. Rosai and ackerman's surgical pathology. $10^{\text {th }}$ edi. Edinburgh: Mosby Elsevier 2011:p1665-8, 1723-5.

4. Rowell MD, Perry RR, Hsiu JG, et al. Phyllodes tumors. American Journal of Surgery 1993;165(3):376-9.

5. Jackin RK, Fridgway PF, Ziprin P, et al. Optimizing preoperative diagnosis in phyllodes tumour of the breast. J Clin Pathol 2006;59(5):454-9.

6. Noguchi $\mathrm{S}$, Motomura $\mathrm{K}$, Inaji $\mathrm{H}$, et al. Clonal analysis of fibroadenoma and phyllodes tumor of the breast. Cancer Res 1993;53(17):4071-4.

7. Noguchi S, Yokouchi H, Aihara T, et al. Progression of fibroadenoma to phyllodes tumor demonstrated by clonal analysis. Cancer 1995;76(10):1779-85.

8. Salvadori B, Cusumano F, Boetal DR, et al. Surgical treatment of phyllodes tumors of the breast. Cancer 1989;63(12):2532-6.

9. Sawyer EJ, Hanby AM, Ellis P, et al. Molecular analysis of phyllodes tumors reveals distinct changes in the epithelial and stromal components. Am J Pathol 2000;156(3):10938.

10. Kuijper A, Buerger H, Simon R, et al. Analysis of progression of fibroepithelial tumors of the breast by PCR based clonality assay. J Pathol 2002;197(5):575-81.

11. Diallo R, Schaefer KL, Poremba C, et al. Monoclonality in normal epithelium and in hyperplastic and neoplastic lesions of the breast. J Pathol 2001;193(1):27-32.

12. Tavassoli F, devilee F. World Health Organization: Tumors of breast and female genital organs. $4^{\text {th }}$ edn. 2003:99-102.

13. Chung EM, Cube R, Hall GJ, et al. From the archives of the AFIP: breast masses in children and adolescents: radiologic-pathologic correlation. Radiographics 2009;29 (3):907-31.
14. Weinstein SP, Conant EF, Orel SG, et al. Spectrum of US findings in pediatric and adolescent patients with palpable breast masses. Radiographics 2000;20(6):1613-21.

15. Wurdinger S, Herzog AB, Fischer DR, et al. Differentiation of phyllodes breast tumors from fibroadenomas on MRI. AJR Am J Roentgenol 2005;185(5):1317-21.

16. Azzopardi JG, Ahmed A, Millis RR. Problems in breast pathology. Major Problems in Pathology 1979;11:1-466.

17. Nabi J, Akhter SM, Authoy FN. A case of large phyllodes tumor causing rupture of the breast: a unique presentation. Case Rep Oncol Med 2013;2013:871292.

18. Scolyer RA, McKenzie PR, Achmed D, et al. Can phyllodes tumors of the breast be distinguished from fibroadenomas using fine needle aspiration cytology? Pathology 2001;33(4):437-43.

19. Raganoonan C, Fairbain JK, Williams S, et al. Giant breast tumours of adolesence. Aust NZ J Surg 1987;57(4):243-7.

20. Bauer BS, Jones KM, Talbot CW. Mammary mass in the adolescent female. Surg gynecol Obstet 1987;165:63-5.

21. Shimizu K, Masawa N, Yamada T, et al. Cytologic evaluation of phyllodes tumors as compared to fibroadenomas of the breast. Acta Cytol 1994;38(6):891-7.

22. Pezner RD, Schultheiss TE, Paz IB. Malignant phyllodes tumor of the breast: local control rates with surgery alone. Int J Radiat Oncol Biol Phys 2008;71(3):710-3.

23. Jones AM, Mitter R, Springall R, et al. A comprehensive genetic profile of phyllodes tumours of the breast detects important mutations, intra-tumoral genetic heterogeneity and new genetic changes on recurrence. J Pathol 2008;214(5):533-44.

24. Wei J, Tan YT, Cai YC, et al. Predictive factors for the local recurrence and distant metastasis of phyllodes tumours of the breast: a retrospective analysis of 192 cases at a single center. Chin J Cancer 2014;33(10):492-500. 